\title{
Hearing assessment during deep brain stimulation of the central nucleus of the inferior colliculus and dentate cerebellar nucleus in rat
}

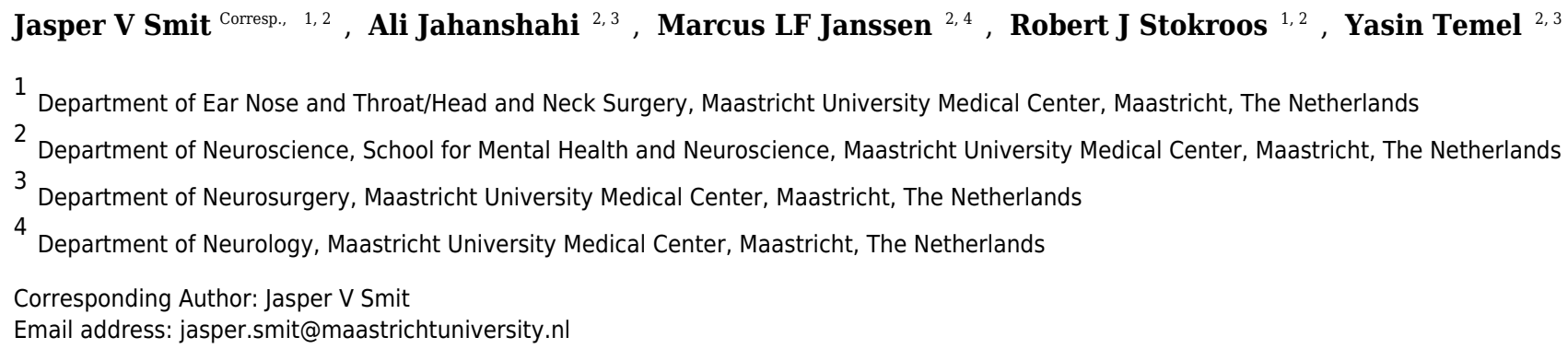

Background. Recently it has been shown in animal studies that deep brain stimulation (DBS) of auditory structures was able to reduce tinnitus-like behavior. However, the question arises whether hearing might be impaired when interfering in auditory-related network loops with DBS.

Methods. The auditory brainstem response (ABR) was measured in rats during high frequency stimulation (HFS) and low frequency stimulation (LFS) in the central nucleus of the inferior colliculus (CIC, $n=5$ ) or dentate cerebellar nucleus ( $D C B N, n=5$ ). Besides hearing thresholds using $A B R$, relative measures of latency and amplitude can be extracted from the ABR. In this study ABR thresholds, interpeak latencies (I-III, III-V, I-V) and V/I amplitude ratio were measured during off-stimulation state and during LFS and HFS.

Results. In both the CIC and the CNBN groups, no significant differences were observed for all outcome measures.

Discussion. DBS in both the $\mathrm{CIC}$ and the CNBN did not have adverse effects on hearing measurements. These findings suggest that DBS does not hamper physiological processing in the auditory circuitry. 


\section{Hearing assessment during deep brain stimulation of the \\ 2 central nucleus of the inferior colliculus and dentate \\ 3 cerebellar nucleus in rat}

4 Smit JV $V^{\mathrm{a}, \mathrm{b}, *}$, Jahanshahi $\mathrm{A}^{\mathrm{b}, \mathrm{c}}$, Janssen MLF ${ }^{\mathrm{b}, \mathrm{d}}$, Stokroos RJ ${ }^{\mathrm{a}, \mathrm{b}}$, Temel $\mathrm{Y}^{\mathrm{b}, \mathrm{c}}$ 5

6 a Department of Ear Nose and Throat/Head and Neck Surgery, ${ }^{b}$ Department of Neuroscience,

7 School for Mental Health and Neuroscience, ${ }^{\mathrm{c}}$ Department of Neurosurgery, ${ }^{\mathrm{d}}$ Department of

8 Neurology, Maastricht University Medical Center, The Netherlands

9

10

$11 *$ Correspondence

12 Jasper Smit

13 Department of Ear Nose and Throat/Head and Neck Surgery

14 Maastricht University Medical Center

15 P. Debyelaan 25, 6202 AZ Maastricht, The Netherlands

16 Tel. 0031-43-3881033, Fax 0031-43-3875580

17 E-mail: jasper.smit@maastrichtuniversity.nl 


\section{Abstract}

26 Background. Recently it has been shown in animal studies that deep brain stimulation (DBS) of

27 auditory structures was able to reduce tinnitus-like behavior. However, the question arises

28 whether hearing might be impaired when interfering in auditory-related network loops with

29 DBS.

30 Methods. The auditory brainstem response (ABR) was measured in rats during high frequency

31 stimulation (HFS) and low frequency stimulation (LFS) in the central nucleus of the inferior

32 colliculus (CIC, $n=5)$ or dentate cerebellar nucleus (DCBN, $n=5)$. Besides hearing thresholds

33 using ABR, relative measures of latency and amplitude can be extracted from the ABR. In this

34 study ABR thresholds, interpeak latencies (I-III, III-V, I-V) and V/I amplitude ratio were

35 measured during off-stimulation state and during LFS and HFS.

36 Results. In both the CIC and the CNBN groups, no significant differences were observed for all 37 outcome measures.

38 Discussion. DBS in both the CIC and the CNBN did not have adverse effects on hearing

39 measurements. These findings suggest that DBS does not hamper physiological processing in the 40 auditory circuitry. 


\section{Introduction}

42 Deep brain stimulation (DBS) in auditory structures has been performed in animal studies as a

43 treatment for tinnitus (Luo et al., 2012; Smit et al., 2016). The rationale behind this treatment is

44 to interfere with the pathological neuronal activity in the central nervous system and interrupt the

45 network loop that is essential for the persistence of tinnitus (Smit et al., 2015).

46 The fundamental knowledge of the effect of deep DBS in auditory structures on hearing is

47 essential before applying this treatment in a clinical setting (Smit et al., 2015). It has been shown

48 in rats, using the sound-induced pre-pulse inhibition test with click stimuli, that during high

49 frequency stimulation (HFS) of the external nucleus of the informed colliculus (IC) hearing

50 thresholds did not change (Smit et al., 2016). As far as we know, a more detailed hearing

51 assessment during DBS in auditory structures has not been assessed thus far.

52 To assess hearing thresholds in more detail, the auditory brainstem response (ABR) was

53 measured in this study. The ABR assesses changes in neural integrity and is commonly used in

54 laboratory animal studies to estimate hearing (Rosahl et al., 2000; Turner et al., 2006). In

55 humans, ABRs are used in daily practice to assess possible hearing loss of a retrocochlear origin

56 (Stockard and Rossiter, 1977).

57 Two structures were targeted in this study, the central nucleus of the IC (CIC) and the dentate 58 cerebellar nucleus (DCBN). The CIC is the principal auditory part of the IC and has a well59 defined tonotopy (Aitkin and Moore, 1975; De Martino et al., 2013). In animal models of

60 tinnitus, the IC shows tonotopic reorganization, increased spontaneous firing rate, increased 61 bursting activity and increased neural synchrony (Bauer et al., 2008; Chen and Jastreboff, 1995;

62 Robertson et al., 2013; Wang, Ding and Salvi, 2002). A recent study showed that HFS of the 
63 external nucleus of the inferior colliculus (IC) in rats decreased tinnitus-like behavior (Smit et

64 al., 2016). The cerebellum is a structure that is not involved in the auditory pathways but is 65 associated with tinnitus (Brozoski, Ciobanu and Bauer, 2007; Osaki et al., 2005; Sedley et al., 66 2012; Shulman and Strashun, 1999). It was demonstrated that ablation of the paraflocculus

67 completely diminished tinnitus in rats (Bauer et al., 2012). The majority of fibers in the 68 cerebellum, including the paraflocculus, originate from the deep cerebellar nuclei, especially the 69 DCBN, which is the largest (Gayer and Faull, 1988; Gould, 1979). Therefore, the CIC and the 70 DCBN could be considered as respectively an auditory and a non-auditory potential DBS target 71 for the treatment of tinnitus.

72 DBS can be performed with low frequency stimulation (LFS), which mainly has an excitatory 73 effect, and as HFS, which generally is described as a global inhibitory effect similar as ablation 74 (Benabid et al., 1998; Breit, Schulz and Benabid, 2004; Dostrovsky and Lozano, 2002). 75 Following ablation of IC in animals models, decreased amplitude and latency of peak V have 76 been found (Achor and Starr, 1980; Buchwald and Huang, 1975; Durrant et al., 1994; Kaga, 77 Shinoda and Suzuki, 1997). Peak V is the last of the five peaks of the ABR and represents neural 78 activity of the IC. Because of a high variability in amplitude among subjects, the V/I amplitude 79 ratio is a more consistent measure than the absolute value (Musiek et al., 1984; Musiek, Reeves 80 and Baran, 1985). The relative measures of the latencies are the interpeak latencies (I-III, III-V, $81 \mathrm{I}-\mathrm{V}$ ) which represent the central transmission latency best (Eggermont and Don, 1986; Picton et 82 al., 1977; Squires, Chu and Starr, 1978). There is little evidence that stimulation of cerebellar 83 structures has influence on the ABR (Crispino and Bullock, 1984).

84 We hypothesize that for CIC stimulation, the V/I amplitude ratio of the ABR would be lower and 85 the I-V or III-V interpeak latencies would be prolonged during HFS and not during LFS of the 
86 CIC. Our hypothesis is that stimulating a non-auditory structure such as the DCBN does not have

87 any influence on the ABR. 


\section{Methods}

90 Animals

91 Male rats (Sprague Dawley, 250-300 g, Charles River, The Netherlands) were housed

92 individually under conditions of constant room temperature and humidity with a reversed

$9312 \mathrm{u} / 12 \mathrm{u}$ light/dark cycle and had free access to water and food. The Animal Experiments

94 Committee of the Maastricht University approved the experiments (approval reference number 95 2012-069).

\section{Surgical procedure}

97 Subcutaneous electrodes were implanted for ABR recordings and during the same surgery DBS

98 electrodes were implanted in the brain (Figure 1). Animals were anesthetized by intraperitoneal 99 administration of ketamine $(90 \mathrm{mg} / \mathrm{kg})$ and xylazine $(10 \mathrm{mg} / \mathrm{kg})$. The head of the rats was 100 immobilized in a stereotactic apparatus (Stoelting Co, Wood Dale, Illinois) with mouth and blunt 101 ear-bars. Permanent Teflon-coated stainless steel electrodes were subcutaneously implanted. One 102 wire electrode was subcutaneously tunneled to the mastoid and a second wire electrode was 103 attached to a screw on the vertex. Based on coordinates from a stereotactic atlas (Paxinos and 104 Watson, 2007), bilateral electrodes (Technomed, Beek, The Netherlands) were inserted in the

105 CIC (bregma -8.8, depth 4.5, interspace 3.8) or in the DCBN (bregma -11.5, depth 6.5, interspace 106 6.8). The postoperative recovery time was one week.

\section{Deep brain stimulation}

108 DBS was performed with bipolar, concentric electrodes using monophasic rectangular pulses.

109 The electrical stimulus pulses were created by an A310 accupulser and an A360 stimulus isolator 
110 (World Precision Instruments, Berlin, Germany). During DBS, stimuli were given with a

111 frequency of $100 \mathrm{~Hz}$ (HFS) and $10 \mathrm{~Hz}$ (LFS) with an amplitude of $100 \mu \mathrm{A}$ and a pulse width of 60

$112 \mu$ s. Electrodes are gold-plated with platinum-iridium inner wire (negative contact) and stainless

113 steel outer part (positive contact). The inner and outer electrodes are insulated except for a $75 \mu \mathrm{m}$

114 exposed tip (Tan et al., 2010).

115 Rats were divided in two groups, one group received implantation of electrodes in the CIC $(\mathrm{n}=5)$

116 and the other group in the DCBN $(n=5)$. In the off-stimulation state, designated as the control

117 situation, no electrical stimulation was given. During stimulation-off state, LFS (10 Hz) and HFS

$118(100 \mathrm{~Hz})$, ABRs were recorded in separate sessions.

119 Auditory brainstem response

120 ABR measurements were performed in a random manner of the three situations (off-stimulation,

121 LFS, HFS) with a one week interval. Stimulation was turned on approximately 5 minutes before

122 ABR recordings. HFS consisted of a concentric bipolar electrode using monophasic rectangular

123 pulses, with a frequency of $100 \mathrm{~Hz}$, amplitude of $100 \mu \mathrm{A}$ per electrode and a pulse width of 60

$124 \mu \mathrm{s}$ (A310 Acupulser, World Precision Instruments, Berlin, Germany). Similar settings were used

125 in a study which showed tinnitus reduction during HFS in rats (Smit et al., 2016). LFS consisted

126 of the same parameters with a frequency of $10 \mathrm{~Hz}$.

127 To achieve anesthesia during ABR recordings, intraperitoneal administration of ketamine (90

$128 \mathrm{mg} / \mathrm{kg}$ ) and xylazine (10 $\mathrm{mg} / \mathrm{kg})$ was used, which is preferred over isoflurane when assessing

129 hearing thresholds in rats (Ruebhausen, Brozoski and Bauer, 2012). 
130 During the ABR procedure, animals were placed into a sound-attenuating chamber. Cables were

131 plugged into the socket of the head of the animal and connected to the recording device

132 (Powerlab 8/35 connected to a Dual Bio Amp amplifier (ADInstruments, Castle Hill, Australia).

133 An electrode connected to the left hind paw served as the ground.

134 Custrom-made auditory stimuli (10, 16, 24 and $32 \mathrm{kHz}$ ) were created with Matlab 2011a

135 (Mathworks, MA, USA) and consisted of $5 \mathrm{~ms}$ bursts with a $\cos ^{2}$ rise and fall filter and were

136 played at a rate of 20 per second at decreasing intensities from 90 to $0 \mathrm{~dB}$ peSPL with steps of 10

$137 \mathrm{~dB}$. To prevent synchronous occurrence of stimulation artifacts with the ABRs, one in 10 stimuli

138 had an interval of $55 \mathrm{~ms}$ instead of $45 \mathrm{~ms}$. To gain an approximately similar amount of data after

139 filtering of stimulation artefacts, 500 auditory stimuli were given per intensity in the off-

140 stimulation state, 700 during LFS and 1000 during HFS. Sounds were calibrated with a Bruel \&

141 Kjaer 2231 decibel meter with a 4191 microphone (range 2-40 kHz), which was placed at the

142 location of the rat's right ear. Sound intensities are reported as the peak equivalent sound

143 pressure level (peSPL).

144 Auditory stimuli were processed with an external soundcard with a sample rate of $192 \mathrm{kHz}$

145 (Creative E-MU 0204), amplified with Ultrasonic power amplifier (Avisoft Bioacoustics, Berlin)

146 and played with an Ultrasonic Dynamic Speaker Vifa (Avisoft Bioacoustics, Berlin, Germany) to

147 the right ear. To standardize sound presentation between recording sessions it was monitored that

148 in every session the same position of the rat and the same distance between the loudspeaker and

149 the ear was used $(2 \mathrm{~cm})$. The contralateral ear was plugged with modeling clay.

150 Auditory stimuli were digitally triggered. The recordings were done in Labchart Pro 7

151 (ADInstruments, Castle Hill, Australia) at a sample frequency of $20 \mathrm{kHz}$ and raw data were 
152 imported into Matlab. With a customized script, the signal was amplified 100,000 times and

153 band-pass filtered (300-3000 Hz). Evoked responses were averaged and data which contained

154 DBS artifacts were automatically removed based on a peak-detection analysis. Using a

155 customized Matlab script, peaks were automatically detected if the signal was above a manual

156 depicted maximal baseline value. Before and after the maximal value of the peak of the artefact

$1572.5 \mathrm{~ms}$ of data were converted in Not-a-Number (NaN). The ABR and DBS stimuli were not

158 phase-locked so per epoch a different part was converted in NaN. All epochs were averaged to

159 calculate the mean ABR signal (Figure 2B).

160 Two independent blinded observers visually identified ABR thresholds and peaks. In case of

161 disagreement, a third observer was sought and the concordant data were accepted. The auditory

162 threshold was defined as the lowest decibel level (peSPL) of the stimulus, which produced a 163 distinctive ABR.

164 For latency analysis, the five positive peaks were determined at $90 \mathrm{~dB}$ peSPL and numbered I-V

165 based on the recordings of vertex upward deflections (for an example see Figure 2C). Latencies

166 of peaks were measured from stimulus onset. Interpeak latency was defined as the time between 167 respective peaks.

168 The amplitude was expressed as the peak-to-peak amplitude ratio of peak V subtracted by peak I.

\section{Electrode localization}

170 Animals were deeply anesthetized with pentobarbital $(75 \mathrm{mg} / \mathrm{kg})$ and perfused transcardially

171 with Tyrode's buffer $(0.1 \mathrm{M})$ and fixative containing 4\% paraformaldehyde, $15 \%$ picric acid and

$1720.05 \%$ glutaraldehyde in $0.1 \mathrm{M}$ phosphate buffer ( $\mathrm{pH} 7.6$ ). After post-fixation for 12 hours, the 
173 brains were cut to coronal sections using a vibrotome. To assess the electrode localization, the

174 sections containing the target area and the electrode trajectory were stained with hematoxylin-

175 eosin (Merck, Darmstadt, Germany). Definition of anatomic structures was based on the

176 stereotactical atlas (Paxinos and Watson, 2007).

177 Statistical analysis

178 Dependent data were analyzed using the Wilcoxon signed-rank Test for two groups and a

179 Friedman test for multiple groups. Since multiple comparisons were made when comparing the

180 stimulation-off state with LFS and HFS, modified $p$-values (alpha $=0.05)$ are given as corrected

181 by means of the Holm-Bonferonni sequential correction (Holm, 1979). Data are presented as

182 mean \pm standard error of the mean (SEM). All data were analyzed with SPSS (Version 20, IBM,

183 Somers, NY, USA).

184 
186 Results

187 Electrode localization

188 Histological evaluation showed that all electrodes were implanted correctly in the target

189 structures (Figures 3A and 3B, respectively).

190 Hearing thresholds

191 Hearing response thresholds were determined as the minimal intensity stimulus at which an ABR

192 was evident. Thresholds of different stimulus frequencies (10, 16, 24 and $32 \mathrm{kHz})$ are depicted in

193 Figure 4A for the CIC group and in Figure 4B for the DCBN group. In one rat two thresholds (10

$194 \mathrm{~Hz}$ LFS and $32 \mathrm{~Hz}$ LFS) were not possible to determine. In both groups, no statistically

195 significant differences were found during HFS and LFS compared to off-stimulation.

196 Latencies and amplitudes

197 From all ABRs, 5 distinctive peaks could be determined at $90 \mathrm{~dB}$ peSPL (Figure 1). In Table 1

198 the mean interpeak latencies (I-III, III-V and I-V) are shown for different burst frequencies (10,

19916,24 and $32 \mathrm{kHz}$ ). In both the CIC and the DCBN group, no statistically significant differences

200 were found for high and low frequency DBS compared to no stimulation (Table 1).

201 The V/I amplitude ratio was calculated at all burst frequencies. In both groups, there was no

202 statistical significant difference when comparing no stimulation with HFS and LFS. Appendix 1

203 shows the absolute latencies and interpeak latencies. 
204 When looking at the latency and amplitude data, a relation between ABR latencies and 205 amplitudes, with frequencies of burst tones was noticed. For further analysis, we grouped the 206 off-stimulation data of the CIC and DCBN group since only baseline measurements were 207 analyzed. The latency, e.g. of peak I, differed between burst frequencies $\left(X^{2}(3)=20.12, p\right.$ $208<0.01$ ). The raw data (see Appendix 1) show a shorter latency with increasing frequencies of 209 burst tones. The V/I amplitude ratio does not differ amongst frequencies $\left(X^{2}(3)=4.92, p=.178\right)$.

210 Amplitudes of peak I did not differ between frequencies $\left(X^{2}(3)=3.240, p=.355\right)$, but the 211 amplitude of peak $\mathrm{V}$ was different between frequencies $\left(X^{2}(3)=17.160, p<0.01\right)$. Also peak $\mathrm{V}$ 212 amplitude decreases with increasing burst frequency.

213

214

215

216

217

218

219 


\section{Discussion}

222

223 We successfully measured ABRs during stimulation-off state, LFS and HFS. Our results showed

224 that LFS as well as HFS in the CIC and DCBN do not influence ABR thresholds, interpeak 225 latencies and amplitude ratios in rats.

\section{ABR thresholds}

227 The finding that ABR thresholds were not influenced by LFS and HFS suggests that hearing in

228 these frequencies is not impaired by DBS. Nonetheless, several caveats must be taken into

229 account when interpreting ABR thresholds. Although common frequencies were tested (10, 16,

23024 and $32 \mathrm{kHz}$ ) in these studies, hearing loss can occur in other specific frequency bands. In rats,

231 hearing thresholds based on ABRs tend to be at least 10-20 dB higher than those determined

232 behaviorally (Borg, 1982; Heffner et al., 1994). The thresholds in the current study (ranging from

23336 to $46 \mathrm{~dB}$ peSPL) are thus an overestimation of the actual hearing level. To get the most

234 reproducible $\mathrm{ABR}$ data in various measurements, we implanted ABR electrodes. In contrast to

235 the commonly used subcutaneous electrodes, these implanted electrodes always measure from

236 exactly the same anatomical position (Buchwald et al., 1981; Hall, 1990; McGee, Ozdamar and

237 Kraus, 1983). To our knowledge, no other studies determined ABR thresholds during HFS and

238 LFS of the CIC or DCBN. Likewise, determination of thresholds in ablation studies, whose 239 results are thought to be similar to HFS, have not been performed.

\section{ABR latency}

241 In addition to thresholds, the latency and amplitude can be extracted from the five ABR peaks.

242 Interpeak latencies are generally accepted as measures of conduction time of the central auditory 
243 pathway (Eggermont and Don, 1986; Picton et al., 1977; Squires, Chu and Starr, 1978). The

244 interpeak latency of waves I-III, III-V and I-V reflect the time to traverse in the caudal, rostral

245 and the whole brainstem, respectively. A prolonged interpeak latency reflects a lesion in central

246 auditory processing (Burkhard, Eggermont and Don, 2007; Hood, 1998). Occasionally, a

247 decreased latency of peak V was noted in ablation studies of the IC. This decrease of peak V

248 latency was only an acute effect (Achor and Starr, 1980).

249 In this study, no statistically significant differences were found between the interpeak latencies at 250 baseline compared to low and high frequency DBS. This can be interpreted as no functional 251 relevant lesion at the IC is induced by DBS. However, many studies found no differences in 252 latencies when ablating the IC, but found a difference in amplitude (Achor and Starr, 1980; 253 Buchwald and Huang, 1975; Caird and Klinke, 1987). Therefore, we also performed analysis of 254 the ABR amplitude.

\section{ABR Amplitude}

256 Synchronously activated neurons contribute to the amplitude of the waveform (Burkhard, 257 Eggermont and Don, 2007). The IC has a central role in the auditory pathway (Aitkin and 258 Moore, 1975; De Martino et al., 2013). Previous studies have shown that lesioning of the IC 259 resulted in a decrease of the amplitude of peak V (Achor and Starr, 1980; Buchwald and Huang, 260 1975; Caird and Klinke, 1987). In most studies a large part or the whole IC was ablated. One 261 study only found an abolished peak $\mathrm{V}$ when ablation of the lateroventral part of the IC, in 262 contrast to ablating the central nucleus (Funai and Funasaka, 1983). In humans, absence of the IC 263 also resulted in abolished peak V peaks (Durrant et al., 1994). It is assumed that electrode 
264 implantation does not influence the amplitude of the evoked potentials, since only minimal tissue

265 damage is seen along the electrode trajectory (Tan et al., 2010).

266 Although the precise role of the cerebellum and its associated nuclei in hearing is not known, it

267 might have a modulatory effect on hearing. The cerebellum receives direct connections from the

268 cochlear nucleus (Huang, Liu and Huang, 1982) and indirect connections from the IC (Aitkin

269 and Boyd, 1978; Huffman and Henson, 1990). Furthermore, auditory stimuli as well as

270 stimulation of the auditory cortex elicited responses from auditory cells in the paraflocculus

271 (Azizi, Burne and Woodward, 1985).

272 One study assessed the ABR during cerebellar stimulation. High frequency stimulation $(400 \mathrm{~Hz})$

273 of the cerebellar surface resulted in a difference of the IV/I amplitude ratio, where peak IV

274 represented in this particular study the IC. The IV/I amplitude ratio increased in case of a short

275 electrical-sound stimulus interval $(<10 \mathrm{~ms})$, and decreased with larger intervals $(>10 \mathrm{~ms})$. In

276 this particular study, peak IV represented the IC (Crispino and Bullock, 1984). In our study, the

277 electrical and sound stimuli were played in an asynchronous manner and therefore various

278 interval times are achieved. This could explain why we did not found any difference in the

279 amplitude ratio. As far as we know, no ABRs were recorded in a cerebellar ablation study.

\section{General ABR findings}

281 It is a well-known phenomenon that high frequency tones show shorter latency peaks than lower

282 frequency sounds, because high frequency sounds stimulate the more basal portions of the basilar

283 membrane (Alvarado et al., 2012). This is also seen in our data. We also found that the peak V

284 amplitude ratio decreased with increasing frequency of the tone given. As far as we know this is 285 a new finding, which has not been reported earlier. 
287 Our results show that latencies were not prolonged and amplitudes were not decreased during 288 DBS, indicating that DBS in the CIC and DCBN probably does not have an overall inhibitory 289 effect on physiological central auditory processing up to the inferior colliculus (peak V). This 290 finding is supported by one of the main working mechanisms of DBS. Namely that DBS with 291 frequencies above $100 \mathrm{~Hz}$ disrupts abnormal information flow in a network (Chiken and Nambu, 292 2014), without influencing the normal neurophysiological activity.

293 HFS is also often referred to as having an inhibitory effect and thus mimicking the effect of a 294 lesion (Benabid et al., 1998; Dostrovsky and Lozano, 2002). The pathological neural network 295 loop related to tinnitus is interrupted by performing HFS within this loop (Smit et al., 2016). This

296 hypothesis is supported by the disruption theory; DBS can dissociate the input and output in a 297 stimulation nucleus and thereby disrupting abnormal information flow such as increased burst 298 activity. Physiological information can still be normally processed through different nuclei

299 (Chiken and Nambu, 2014). It can be hypothesized that this is the same when DBS is applied in 300 the auditory pathway and physiological auditory information processing remains intact.

\section{Future studies}

302 In the current study animal did not receive noise trauma for induction of tinnitus. We 303 hypothesize that if DBS does not result in hearing loss in the normal hearing, this will also not be 304 the case when there is hearing loss in association with tinnitus. The current stimulation 305 parameters can be used for tinnitus treatment; in a recent study that showed a decrease of tinnitus 306 during IC stimulation (Smit et al., 2016), the same stimulation parameters were used as in the 307 current study. In our study no pre-operative assessment of the ABR was performed. 


\section{Conclusions}

309 In conclusion, HFS and LFS in the CIC and DCBN did not result in increased ABR thresholds

310 and changes in interpeak latencies. Based on these observations no evidence for changes in

311 information processing in the auditory circuit were found during low and high frequency DBS in

312 the CIC and DCBN. These findings suggest that DBS in the auditory pathways can be performed

313 without hampering physiological processing of auditory information. 


\section{References}

316 Achor, L.J., Starr, A., 1980. Auditory brain stem responses in the cat. II. Effects of lesions. Electroencephalogr Clin Neurophysiol. 48, 174-90.

Aitkin, L.M., Moore, D.R., 1975. Inferior colliculus. II. Development of tuning characteristics and tonotopic organization in central nucleus of the neonatal cat. J Neurophysiol. 38, 1208-16.

Aitkin, L.M., Boyd, J., 1978. Acoustic input to the lateral pontine nuclei. Hear Res. 1, 67-77.

Alvarado, J.C., Fuentes-Santamaria, V., Jareno-Flores, T., Blanco, J.L., Juiz, J.M., 2012. Normal variations in the morphology of auditory brainstem response (ABR) waveforms: a study in Wistar rats. Neurosci Res. 73, 302-11.

Azizi, S.A., Burne, R.A., Woodward, D.J., 1985. The auditory corticopontocerebellar projection in the rat: inputs to the paraflocculus and midvermis. An anatomical and physiological study. Exp Brain Res. 59, 36-49.

Bauer, C.A., Turner, J.G., Caspary, D.M., Myers, K.S., Brozoski, T.J., 2008. Tinnitus and inferior colliculus activity in chinchillas related to three distinct patterns of cochlear trauma. J Neurosci Res. 86, 2564-78.

Bauer, C.A., Kurt, W., Sybert, L.T., Brozoski, T.J., 2012. The cerebellum as a novel tinnitus generator. Hearing Research.

Benabid, A.L., Benazzouz, A., Hoffmann, D., Limousin, P., Krack, P., Pollak, P., 1998. Longterm electrical inhibition of deep brain targets in movement disorders. Mov Disord. 13 Suppl 3, 119-25.

Borg, E., 1982. Auditory thresholds in rats of different age and strain. A behavioral and electrophysiological study. Hear Res. 8, 101-15.

Breit, S., Schulz, J.B., Benabid, A.L., 2004. Deep brain stimulation. Cell Tissue Res. 318, 27588.

Brozoski, T.J., Ciobanu, L., Bauer, C.A., 2007. Central neural activity in rats with tinnitus evaluated with manganese-enhanced magnetic resonance imaging (MEMRI). Hear Res. 228, 168-79.

Buchwald, J.S., Huang, C., 1975. Far-field acoustic response: origins in the cat. Science. 189, 382-4.

Buchwald, J.S., Hinman, C., Norman, R.J., Huang, C.M., Brown, K.A., 1981. Middle- and longlatency auditory evoked responses recorded from the vertex of normal and chronically lesioned cats. Brain Res. 205, 91-109.

Burkhard, R.F., Eggermont, J.J., Don, M., 2007. Auditory evoked potentials: basic principles and clinical application, Vol., Lippincott/Williams \& Wilkins, Philadelphia/Baltimore.

Caird, D.M., Klinke, R., 1987. The effect of inferior colliculus lesions on auditory evoked potentials. Electroencephalogr Clin Neurophysiol. 68, 237-40.

Chen, G.D., Jastreboff, P.J., 1995. Salicylate-induced abnormal activity in the inferior colliculus of rats. Hear Res. 82, 158-78.

Chiken, S., Nambu, A., 2014. Disrupting neuronal transmission: mechanism of DBS? Front Syst Neurosci. 8, 33.

Crispino, L., Bullock, T.H., 1984. Cerebellum mediates modality-specific modulation of sensory responses of midbrain and forebrain in rat. Proceedings of the National Academy of Sciences of the United States of America. 81, 2917-20. 
359

360

361

362

363

364

365

366

367

368

369

370

371

372

373

374

375

376

377

378

379

380

381

382

383

384

385

386

387

388

389

390

391

392

393

394

395

396

397

398

399

400

401

402

403

De Martino, F., Moerel, M., van de Moortele, P.F., Ugurbil, K., Goebel, R., Yacoub, E., Formisano, E., 2013. Spatial organization of frequency preference and selectivity in the human inferior colliculus. Nat Commun. 4, 1386.

Dostrovsky, J.O., Lozano, A.M., 2002. Mechanisms of deep brain stimulation. Mov Disord. 17 Suppl 3, S63-8.

Durrant, J.D., Martin, W.H., Hirsch, B., Schwegler, J., 1994. 3CLT ABR analyses in a human subject with unilateral extirpation of the inferior colliculus. Hear Res. 72, 99-107.

Eggermont, J.J., Don, M., 1986. Mechanisms of central conduction time prolongation in brainstem auditory evoked potentials. Arch Neurol. 43, 116-20.

Funai, H., Funasaka, S., 1983. Experimental study on the effect of inferior colliculus lesions upon auditory brain stem response. Audiology. 22, 9-19.

Gayer, N.S., Faull, R.L., 1988. Connections of the paraflocculus of the cerebellum with the superior colliculus in the rat brain. Brain Res. 449, 253-70.

Gould, B.B., 1979. The organization of afferents to the cerebellar cortex in the cat: projections from the deep cerebellar nuclei. J Comp Neurol. 184, 27-42.

Hall, R.D., 1990. Estimation of surviving spiral ganglion cells in the deaf rat using the electrically evoked auditory brainstem response. Hear Res. 49, 155-68.

Heffner, H.E., Heffner, R.S., Contos, C., Ott, T., 1994. Audiogram of the hooded Norway rat. Hear Res. 73, 244-7.

Holm, S., 1979. A simple sequential rejective method procedure. Scandinavian Journal of Statistics. 6, 65-70.

Hood, L.J., 1998. Clinical applications of the Auditory Brainstem Response, Vol., Singular Publishing Group, San Diego.

Huang, C.M., Liu, G., Huang, R., 1982. Projections from the cochlear nucleus to the cerebellum. Brain Res. 244, 1-8.

Huffman, R.F., Henson, O.W., Jr., 1990. The descending auditory pathway and acousticomotor systems: connections with the inferior colliculus. Brain Res Brain Res Rev. 15, 295-323.

Kaga, K., Shinoda, Y., Suzuki, J.I., 1997. Origin of auditory brainstem responses in cats: whole brainstem mapping, and a lesion and HRP study of the inferior colliculus. Acta Otolaryngol. 117, 197-201.

Luo, H., Zhang, X., Nation, J., Pace, E., Lepczyk, L., Zhang, J., 2012. Tinnitus suppression by electrical stimulation of the rat dorsal cochlear nucleus. Neurosci Lett.

McGee, T.J., Ozdamar, O., Kraus, N., 1983. Auditory middle latency responses in the guinea pig. Am J Otolaryngol. 4, 116-22.

Musiek, F.E., Kibbe, K., Rackliffe, L., Weider, D.J., 1984. The auditory brain stem response I-V amplitude ratio in normal, cochlear, and retrocochlear ears. Ear Hear. 5, 52-5.

Musiek, F.E., Reeves, A.G., Baran, J.A., 1985. Release from central auditory competition in the split-brain patient. Neurology. 35, 983-7.

Osaki, Y., Nishimura, H., Takasawa, M., Imaizumi, M., Kawashima, T., Iwaki, T., Oku, N., Hashikawa, K., Doi, K., Nishimura, T., Hatazawa, J., Kubo, T., 2005. Neural mechanism of residual inhibition of tinnitus in cochlear implant users. Neuroreport. 16, 1625-8.

Paxinos, G., Watson, C., 2007. The Rat Brain in Stereotaxic Coordinates, Vol., Academic Press, London.

Picton, T.W., Woods, D.L., Barobeau-Brain, J.B.A., Healeu, T.M.G., 1977. Evoked Potential Audiometry. Journal of Otolaryngology. 6, 90-119. 
404

405

406

407

408

409

410

411

412

413

414

415

416

417

418

419

420

421

422

423

424

425

426

427

428

429

430

431

432

433

434
Robertson, D., Bester, C., Vogler, D., Mulders, W.H., 2013. Spontaneous hyperactivity in the auditory midbrain: relationship to afferent input. Hear Res. 295, 124-9.

Rosahl, S.K., Tatagiba, M., Gharabaghi, A., Matthies, C., Samii, M., 2000. Acoustic evoked response following transection of the eighth nerve in the rat. Acta Neurochir (Wien). 142, 1037-45.

Ruebhausen, M.R., Brozoski, T.J., Bauer, C.A., 2012. A comparison of the effects of isoflurane and ketamine anesthesia on auditory brainstem response (ABR) thresholds in rats. Hear Res. 287, 25-9.

Sedley, W., Teki, S., Kumar, S., Barnes, G.R., Bamiou, D.E., Griffiths, T.D., 2012. Singlesubject oscillatory gamma responses in tinnitus. Brain.

Shulman, A., Strashun, A., 1999. Descending auditory system/cerebellum/tinnitus. Int Tinnitus J. 5, 92-106.

Smit, J.V., Janssen, M.L., Schulze, H., Jahanshahi, A., Van Overbeeke, J.J., Temel, Y., Stokroos, R.J., 2015. Deep brain stimulation in tinnitus: current and future perspectives. Brain Res. 1608, 51-65.

Smit, J.V., Janssen, M.L., van Zwieten, G., Jahanshahi, A., Temel, Y., Stokroos, R.J., 2016. Deep brain stimulation of the inferior colliculus in the rodent suppresses tinnitus. Brain Res.

Squires, K.C., Chu, N.S., Starr, A., 1978. Auditory brain stem potentials with alcohol. Electroencephalogr Clin Neurophysiol. 45, 577-84.

Stockard, J.J., Rossiter, V.S., 1977. Clinical and pathologic correlates of brain stem auditory response abnormalities. Neurology. 27, 316-25.

Tan, S., Vlamings, R., Lim, L., Sesia, T., Janssen, M.L., Steinbusch, H.W., Visser-Vandewalle, V., Temel, Y., 2010. Experimental deep brain stimulation in animal models. Neurosurgery. 67, 1073-9; discussion1080.

Turner, J.G., Brozoski, T.J., Bauer, C.A., Parrish, J.L., Myers, K., Hughes, L.F., Caspary, D.M., 2006. Gap detection deficits in rats with tinnitus: a potential novel screening tool. Behav Neurosci. 120, 188-95.

Wang, J., Ding, D., Salvi, R.J., 2002. Functional reorganization in chinchilla inferior colliculus associated with chronic and acute cochlear damage. Hear Res. 168, 238-49. 
435 Appendix: Absolute values of latencies and amplitudes

436

437 Table 1: Absolute values of latencies and amplitudes from the five peaks of the auditory

438 brainstem response of $10 \mathrm{kHz}$ auditory stimuli. Mean values with standard deviation are given.

\begin{tabular}{|c|c|c|c|c|c|c|c|}
\hline \multirow[t]{2}{*}{ Peak } & \multirow[t]{2}{*}{ Wave } & \multicolumn{3}{|c|}{ CIC group } & \multicolumn{3}{|c|}{ DCBN group } \\
\hline & & Stim-off & LFS & HFS & Stim-off & LFS & HFS \\
\hline \multirow[t]{5}{*}{ Latencies } & I & $\begin{array}{l}1.639 \\
(.073)\end{array}$ & $\begin{array}{l}1.599 \\
(.110)\end{array}$ & $\begin{array}{l}1.618 \\
(.080)\end{array}$ & $\begin{array}{l}1.540 \\
(.165)\end{array}$ & $\begin{array}{l}1.490 \\
(.076)\end{array}$ & $\begin{array}{l}1.570 \\
(.090)\end{array}$ \\
\hline & II & $\begin{array}{l}2.460 \\
(.092)\end{array}$ & $\begin{array}{l}2.479 \\
(.121)\end{array}$ & $\begin{array}{l}2.392 \\
(.079)\end{array}$ & $\begin{array}{l}2.386 \\
(.162)\end{array}$ & $\begin{array}{l}2.325 \\
(.066)\end{array}$ & $\begin{array}{l}2.356 \\
(.083)\end{array}$ \\
\hline & III & $\begin{array}{l}3.143 \\
(.181)\end{array}$ & $\begin{array}{l}3.122 \\
(.208)\end{array}$ & $\begin{array}{l}3.088 \\
(.144)\end{array}$ & $\begin{array}{l}3.060 \\
(.280)\end{array}$ & $\begin{array}{l}3.080 \\
(.109)\end{array}$ & $\begin{array}{l}3.101 \\
(.084)\end{array}$ \\
\hline & IV & $\begin{array}{l}4.288 \\
(.281)\end{array}$ & $\begin{array}{l}4.167 \\
(.191)\end{array}$ & $\begin{array}{l}4.122 \\
(.238)\end{array}$ & $\begin{array}{l}4.077 \\
(.260)\end{array}$ & $\begin{array}{l}4.118 \\
(.165)\end{array}$ & $\begin{array}{l}4.148 \\
(.098)\end{array}$ \\
\hline & $\mathrm{V}$ & $\begin{array}{l}5.050 \\
(.275)\end{array}$ & $\begin{array}{l}5.047 \\
(.180)\end{array}$ & $\begin{array}{l}4.765 \\
(.291)\end{array}$ & $\begin{array}{l}4.903 \\
(.270)\end{array}$ & $\begin{array}{l}4.923 \\
(.206)\end{array}$ & $\begin{array}{l}4.983 \\
(.015)\end{array}$ \\
\hline \multirow[t]{5}{*}{ Amplitudes } & I & $\begin{array}{l}.007 \\
(.018)\end{array}$ & $\begin{array}{l}.028 \\
(.030)\end{array}$ & $\begin{array}{l}.037 \\
(.042)\end{array}$ & $\begin{array}{l}.030 \\
(.016)\end{array}$ & $\begin{array}{l}.030 \\
(.011)\end{array}$ & $\begin{array}{l}.041 \\
(.047)\end{array}$ \\
\hline & II & $\begin{array}{l}.221 \\
(.018)\end{array}$ & $\begin{array}{l}.218 \\
(.042)\end{array}$ & $\begin{array}{l}.252 \\
(.054)\end{array}$ & $\begin{array}{l}.159 \\
(.012)\end{array}$ & $\begin{array}{l}.181 \\
(.009)\end{array}$ & $\begin{array}{l}.185 \\
(.048)\end{array}$ \\
\hline & III & $\begin{array}{l}.042 \\
(.018)\end{array}$ & \begin{tabular}{|l|}
.074 \\
$(.037)$
\end{tabular} & $\begin{array}{l}.076 \\
(.038)\end{array}$ & $\begin{array}{l}.078 \\
(.031)\end{array}$ & $\begin{array}{l}.097 \\
(.066)\end{array}$ & $\begin{array}{l}.117 \\
(.069)\end{array}$ \\
\hline & IV & $\begin{array}{l}.070 \\
(.017)\end{array}$ & $\begin{array}{l}.086 \\
(.042)\end{array}$ & $\begin{array}{l}.117 \\
(.035)\end{array}$ & $\begin{array}{l}.061 \\
(.055)\end{array}$ & $\begin{array}{l}.087 \\
(.041)\end{array}$ & $\begin{array}{l}.103 \\
(.053)\end{array}$ \\
\hline & $\mathrm{V}$ & $\begin{array}{l}.030 \\
(.059)\end{array}$ & $\begin{array}{l}.054 \\
(.049)\end{array}$ & $\begin{array}{l}.063 \\
(.043)\end{array}$ & $\begin{array}{l}.077 \\
(.028)\end{array}$ & $\begin{array}{l}.069 \\
(.023)\end{array}$ & $\begin{array}{l}.093 \\
(.039)\end{array}$ \\
\hline
\end{tabular}


439 Abbreviations: $\mathrm{CIC}=$ central nucleus of interior colliculus, $\mathrm{DCBN}=$ dentate cerebellar nucleus, 440 stim-off $=$ stimulation-off state, LFS $=$ deep brain stimulation at $10 \mathrm{~Hz}$, HFS = deep brain 441 stimulation at $100 \mathrm{~Hz}$.

442 Table 2: Absolute values of latencies and amplitudes from the five peaks of the auditory 443 brainstem response of $16 \mathrm{kHz}$ auditory stimuli. Mean values with standard deviation are given.

\begin{tabular}{|c|c|c|c|c|c|c|c|}
\hline \multirow[t]{2}{*}{ Peak } & \multirow[t]{2}{*}{ Wave } & \multicolumn{3}{|c|}{ CIC group } & \multicolumn{3}{|c|}{ DCBN group } \\
\hline & & Stim-off & LFS & HFS & Stim-off & LFS & HFS \\
\hline \multirow[t]{5}{*}{ Latencies } & I & $\begin{array}{l}1.400 \\
(.153)\end{array}$ & $\begin{array}{l}1.419 \\
(.042)\end{array}$ & $\begin{array}{l}1.530 \\
(.076)\end{array}$ & $\begin{array}{l}1.399 \\
(.042)\end{array}$ & $\begin{array}{l}1.389 \\
(.027)\end{array}$ & $\begin{array}{l}1.470 \\
(.066)\end{array}$ \\
\hline & II & $\begin{array}{l}2.245 \\
(.153)\end{array}$ & $\begin{array}{l}2.275 \\
(.055)\end{array}$ & $\begin{array}{l}2.325 \\
(.075)\end{array}$ & $\begin{array}{l}2.215 \\
(.128)\end{array}$ & $\begin{array}{l}2.285 \\
(.084)\end{array}$ & $\begin{array}{l}2.275 \\
(.065)\end{array}$ \\
\hline & III & $\begin{array}{l}2.960 \\
(.292)\end{array}$ & $\begin{array}{l}2.960 \\
(.125)\end{array}$ & $\begin{array}{l}3.020 \\
(.155)\end{array}$ & $\begin{array}{l}2.96 \\
(.140)\end{array}$ & $\begin{array}{l}2.929 \\
(.075)\end{array}$ & $\begin{array}{l}3.030 \\
(.090)\end{array}$ \\
\hline & IV & $\begin{array}{l}3.956 \\
(.367)\end{array}$ & $\begin{array}{l}4.067 \\
(.190)\end{array}$ & $\begin{array}{l}4.057 \\
(.230)\end{array}$ & $\begin{array}{l}3.977 \\
(.118)\end{array}$ & $\begin{array}{l}4.027 \\
(.155)\end{array}$ & $\begin{array}{l}4.098 \\
(.145)\end{array}$ \\
\hline & $\mathrm{V}$ & $\begin{array}{l}4.782 \\
(.534)\end{array}$ & $\begin{array}{l}4.903 \\
(.206)\end{array}$ & $\begin{array}{l}4.883 \\
(.249)\end{array}$ & $\begin{array}{l}4.822 \\
(.240)\end{array}$ & $\begin{array}{l}4.863 \\
(.213)\end{array}$ & $\begin{array}{l}4.993 \\
(.120)\end{array}$ \\
\hline \multirow[t]{5}{*}{ Amplitudes } & $\mathrm{I}$ & $\begin{array}{l}.042 \\
(.040)\end{array}$ & $\begin{array}{l}.039 \\
(.031)\end{array}$ & $\begin{array}{l}.037 \\
(.027)\end{array}$ & $\begin{array}{l}.036 \\
(.018)\end{array}$ & $\begin{array}{l}.025 \\
(.016)\end{array}$ & $\begin{array}{l}.058 \\
(.046)\end{array}$ \\
\hline & II & $\begin{array}{l}.182 \\
(.028)\end{array}$ & $\begin{array}{l}.162 \\
(.030)\end{array}$ & $\begin{array}{l}.189 \\
(.043)\end{array}$ & $\begin{array}{l}.139 \\
(.052)\end{array}$ & $\begin{array}{l}.119 \\
(.018)\end{array}$ & $\begin{array}{l}.178 \\
(.023)\end{array}$ \\
\hline & III & $\begin{array}{l}.079 \\
(.048)\end{array}$ & $\begin{array}{l}.080 \\
(.048)\end{array}$ & $\begin{array}{l}.085 \\
(.029)\end{array}$ & $\begin{array}{l}.088 \\
(.047)\end{array}$ & $\begin{array}{l}.079 \\
(.040)\end{array}$ & $\begin{array}{l}.118 \\
(.052)\end{array}$ \\
\hline & IV & $\begin{array}{l}.050 \\
(.019)\end{array}$ & $\begin{array}{l}.057 \\
(.031)\end{array}$ & $\begin{array}{l}.089 \\
(.029)\end{array}$ & $\begin{array}{l}.047 \\
(.015)\end{array}$ & $\begin{array}{l}.072 \\
(.030)\end{array}$ & $\begin{array}{l}.113 \\
(.035)\end{array}$ \\
\hline & $\mathrm{V}$ & $\begin{array}{l}.067 \\
(.047)\end{array}$ & $\begin{array}{l}.050 \\
(.028)\end{array}$ & $\begin{array}{l}.077 \\
(.029)\end{array}$ & $\begin{array}{l}.080 \\
(.089)\end{array}$ & $\begin{array}{l}.034 \\
(.023)\end{array}$ & $\begin{array}{l}.086 \\
(.040)\end{array}$ \\
\hline
\end{tabular}


444 Abbreviations: $\mathrm{CIC}=$ central nucleus of interior colliculus, $\mathrm{DCBN}=$ dentate cerebellar nucleus,

445 stim-off $=$ stimulation-off state, LFS $=$ deep brain stimulation at $10 \mathrm{~Hz}$, HFS $=$ deep brain

446 stimulation at $100 \mathrm{~Hz}$.

447 
448 Table 3: Absolute values of latencies and amplitudes from the five peaks of the auditory

449 brainstem response of $24 \mathrm{kHz}$ auditory stimuli. Mean values with standard deviation are given.

\begin{tabular}{|c|c|c|c|c|c|c|c|}
\hline \multirow[t]{2}{*}{ Peak } & \multirow[t]{2}{*}{ Wave } & \multicolumn{3}{|c|}{ CIC group } & \multicolumn{3}{|c|}{ DCBN group } \\
\hline & & Stim-off & LFS & HFS & Stim-off & LFS & HFS \\
\hline \multirow[t]{5}{*}{ Latencies } & I & $\begin{array}{l}1.379 \\
(.126)\end{array}$ & $\begin{array}{l}1.379 \\
(.027)\end{array}$ & $\begin{array}{l}1.480 \\
(.131)\end{array}$ & $\begin{array}{l}1.299 \\
(.083)\end{array}$ & $\begin{array}{l}1.399 \\
(.075)\end{array}$ & $\begin{array}{l}1.419 \\
(.066)\end{array}$ \\
\hline & II & $\begin{array}{l}2.235 \\
(.200)\end{array}$ & $\begin{array}{l}2.215 \\
(.071)\end{array}$ & $\begin{array}{l}2.293 \\
(.111)\end{array}$ & $\begin{array}{l}2.134 \\
(.116)\end{array}$ & $\begin{array}{l}2.225 \\
(.083)\end{array}$ & $\begin{array}{l}2.305 \\
(.066)\end{array}$ \\
\hline & III & $\begin{array}{l}2.929 \\
(.234)\end{array}$ & $\begin{array}{l}2.929 \\
(.114)\end{array}$ & $\begin{array}{l}3.050 \\
(.131)\end{array}$ & $\begin{array}{l}2.859 \\
(.140)\end{array}$ & $\begin{array}{l}2.919 \\
(.094)\end{array}$ & $\begin{array}{l}3.040 \\
(.121)\end{array}$ \\
\hline & IV & $\begin{array}{l}3.896 \\
(.326)\end{array}$ & $\begin{array}{l}3.987 \\
(.186)\end{array}$ & $\begin{array}{l}4.097 \\
(.272)\end{array}$ & $\begin{array}{l}3.906 \\
(.170)\end{array}$ & $\begin{array}{l}4.007 \\
(.116)\end{array}$ & $\begin{array}{l}4.108 \\
(.166)\end{array}$ \\
\hline & $\mathrm{V}$ & $\begin{array}{l}4.782 \\
(.391)\end{array}$ & $\begin{array}{l}4.933 \\
(.228)\end{array}$ & $\begin{array}{l}5.023 \\
(.262)\end{array}$ & $\begin{array}{l}4.570 \\
(.215)\end{array}$ & $\begin{array}{l}4.812 \\
(.275)\end{array}$ & $\begin{array}{l}4.790 \\
(.129)\end{array}$ \\
\hline \multirow[t]{5}{*}{ Amplitudes } & I & $\begin{array}{l}.026 \\
(.025)\end{array}$ & $\begin{array}{l}.023 \\
(.038)\end{array}$ & $\begin{array}{l}.033 \\
(.027)\end{array}$ & $\begin{array}{l}.032 \\
(.011)\end{array}$ & $\begin{array}{l}.028 \\
(.014)\end{array}$ & $\begin{array}{l}.046 \\
(.045)\end{array}$ \\
\hline & II & $\begin{array}{l}.116 \\
(.020)\end{array}$ & $\begin{array}{l}.094 \\
(.020)\end{array}$ & $\begin{array}{l}.110 \\
(.028)\end{array}$ & $\begin{array}{l}.090 \\
(.016)\end{array}$ & $\begin{array}{l}.088 \\
(.015)\end{array}$ & $\begin{array}{l}.117 \\
(.029)\end{array}$ \\
\hline & III & $\begin{array}{l}.080 \\
(.062)\end{array}$ & $\begin{array}{l}.072 \\
(.062)\end{array}$ & $\begin{array}{l}.074 \\
(.031)\end{array}$ & $\begin{array}{l}.070 \\
(.033)\end{array}$ & $\begin{array}{l}.055 \\
(.034)\end{array}$ & $\begin{array}{l}.085 \\
(.072)\end{array}$ \\
\hline & IV & $\begin{array}{l}.037 \\
(.033)\end{array}$ & $\begin{array}{l}.192 \\
(.301)\end{array}$ & $\begin{array}{l}.083 \\
(.054)\end{array}$ & $\begin{array}{l}.053 \\
(.024)\end{array}$ & $\begin{array}{l}.054 \\
(.009)\end{array}$ & $\begin{array}{l}.077 \\
(.041)\end{array}$ \\
\hline & $\mathrm{V}$ & $\begin{array}{l}.034 \\
(.036)\end{array}$ & $\begin{array}{l}.033 \\
(.045)\end{array}$ & $\begin{array}{l}.043 \\
(.028)\end{array}$ & $\begin{array}{l}.022 \\
(.014)\end{array}$ & $\begin{array}{l}.013 \\
(.013)\end{array}$ & $\begin{array}{l}.050 \\
(.039)\end{array}$ \\
\hline
\end{tabular}

450 Abbreviations: $\mathrm{CIC}=$ central nucleus of interior colliculus, $\mathrm{DCBN}=$ dentate cerebellar nucleus,

451 stim-off $=$ stimulation-off state, $\mathrm{LFS}=$ deep brain stimulation at $10 \mathrm{~Hz}, \mathrm{HFS}=$ deep brain

452 stimulation at $100 \mathrm{~Hz}$. 
454 Table 4: Absolute values of latencies and amplitudes from the five peaks of the auditory 455 brainstem response of $32 \mathrm{kHz}$ auditory stimuli. Mean values with standard deviation are given.

\begin{tabular}{|c|c|c|c|c|c|c|c|}
\hline \multirow[t]{2}{*}{ Peak } & \multirow[t]{2}{*}{ Wave } & \multicolumn{3}{|c|}{ CIC group } & \multicolumn{3}{|c|}{ DCBN group } \\
\hline & & Stim-off & LFS & HFS & Stim-off & LFS & HFS \\
\hline \multirow[t]{5}{*}{ Latencies } & $\mathrm{I}$ & $\begin{array}{l}1.369 \\
(.826)\end{array}$ & $\begin{array}{l}1.408 \\
(.051)\end{array}$ & $\begin{array}{l}1.497 \\
(.188)\end{array}$ & $\begin{array}{l}1.289 \\
(.104)\end{array}$ & $\begin{array}{l}1.268 \\
(.042)\end{array}$ & $\begin{array}{l}1.409 \\
(.155)\end{array}$ \\
\hline & II & $\begin{array}{l}2.235 \\
(.145)\end{array}$ & $\begin{array}{l}2.222 \\
(.106)\end{array}$ & $\begin{array}{l}2.272 \\
(.122)\end{array}$ & $\begin{array}{l}2.104 \\
(.180)\end{array}$ & $\begin{array}{l}1.980 \\
(.444)\end{array}$ & $\begin{array}{l}2.325 \\
(.153)\end{array}$ \\
\hline & III & $\begin{array}{l}2.919 \\
(.155)\end{array}$ & $\begin{array}{l}2.885 \\
(.124)\end{array}$ & $\begin{array}{l}2.926 \\
(.139)\end{array}$ & $\begin{array}{l}2.859 \\
(1.80)\end{array}$ & $\begin{array}{l}2.789 \\
(.098)\end{array}$ & $\begin{array}{l}2.980 \\
(.199)\end{array}$ \\
\hline & IV & $\begin{array}{l}3.946 \\
(.210)\end{array}$ & $\begin{array}{l}3.912 \\
(.130)\end{array}$ & $\begin{array}{l}3.982 \\
(.207)\end{array}$ & $\begin{array}{l}3.866 \\
(.232)\end{array}$ & $\begin{array}{l}4.097 \\
(.614)\end{array}$ & $\begin{array}{l}4.027 \\
(.216)\end{array}$ \\
\hline & $\mathrm{V}$ & $\begin{array}{l}4.802 \\
(.413)\end{array}$ & $\begin{array}{l}4.896 \\
(.371)\end{array}$ & $\begin{array}{l}4.776 \\
(.304)\end{array}$ & $\begin{array}{l}4.681 \\
(.222)\end{array}$ & $\begin{array}{l}4.691 \\
(.271)\end{array}$ & $\begin{array}{l}4.842 \\
(.277)\end{array}$ \\
\hline \multirow[t]{5}{*}{ Amplitudes } & I & $\begin{array}{l}.017 \\
(.011)\end{array}$ & $\begin{array}{l}.024 \\
(.032)\end{array}$ & $\begin{array}{l}.052 \\
(.124)\end{array}$ & $\begin{array}{l}.035 \\
(.017)\end{array}$ & $\begin{array}{l}.023 \\
(.013)\end{array}$ & $\begin{array}{l}.043 \\
(.041)\end{array}$ \\
\hline & II & $\begin{array}{l}.097 \\
(.019)\end{array}$ & $\begin{array}{l}.156 \\
(.150)\end{array}$ & $\begin{array}{l}.167 \\
(.225)\end{array}$ & $\begin{array}{l}.078 \\
(.021)\end{array}$ & $\begin{array}{l}.091 \\
(.030)\end{array}$ & $\begin{array}{l}.092 \\
(.030)\end{array}$ \\
\hline & III & $\begin{array}{l}.062 \\
(.015)\end{array}$ & $\begin{array}{l}.093 \\
(.091)\end{array}$ & $\begin{array}{l}.134 \\
(.145)\end{array}$ & $\begin{array}{l}.058 \\
(.031)\end{array}$ & $\begin{array}{l}.056 \\
(.063)\end{array}$ & $\begin{array}{l}.058 \\
(.040)\end{array}$ \\
\hline & IV & $\begin{array}{l}.057 \\
(.048)\end{array}$ & $\begin{array}{l}.129 \\
(.141)\end{array}$ & $\begin{array}{l}.190 \\
(.268)\end{array}$ & $\begin{array}{l}.034 \\
(.026)\end{array}$ & $\begin{array}{l}.048 \\
(.028)\end{array}$ & $\begin{array}{l}.066 \\
(.042)\end{array}$ \\
\hline & $\mathrm{V}$ & $\begin{array}{l}.021 \\
(.022)\end{array}$ & $\begin{array}{l}.032 \\
(.054)\end{array}$ & $\begin{array}{l}.039 \\
(.090)\end{array}$ & $\begin{array}{l}.015 \\
(.146)\end{array}$ & $\begin{array}{l}.013 \\
(.025)\end{array}$ & $\begin{array}{l}0.042 \\
(.043)\end{array}$ \\
\hline
\end{tabular}

456 Abbreviations: $\mathrm{CIC}=$ central nucleus of interior colliculus, $\mathrm{DCBN}=$ dentate cerebellar nucleus,

457 stim-off $=$ stimulation-off state, $\mathrm{LFS}=$ deep brain stimulation at $10 \mathrm{~Hz}, \mathrm{HFS}=$ deep brain 458 stimulation at $100 \mathrm{~Hz}$. 


\section{Table $\mathbf{1}$ (on next page)}

Interpeak latencies (IL) and V/I amplitude ratio (AR) for 10k, 16k, 24k and 32k burst sounds. Mean values with standard deviation are given. Adjusted Holm-Bonferroni $p$ values are used. 
1

\begin{tabular}{|c|c|c|c|c|c|c|c|c|c|c|c|}
\hline \multirow{2}{*}{$\begin{array}{l}\text { Frequ } \\
\text { ency } \\
(\mathrm{Hz})\end{array}$} & \multirow[t]{2}{*}{ Peaks } & \multicolumn{5}{|c|}{ CIC group } & \multicolumn{5}{|c|}{ DCBN group } \\
\hline & & Stim-off & LFS & $p$ & HFS & $p$ & Stim-off & LFS & $p$ & HFS & $p$ \\
\hline \multirow[t]{4}{*}{$10 k$} & IL I-III & $\begin{array}{l}1.504 \\
(.170)\end{array}$ & $\begin{array}{l}1.524 \\
(.125)\end{array}$ & $>.99$ & $\begin{array}{l}1.470 \\
(.285)\end{array}$ & $>.99$ & $\begin{array}{l}1.520 \\
(.157)\end{array}$ & $\begin{array}{l}1.590 \\
(.162)\end{array}$ & 0.20 & $\begin{array}{l}1.530 \\
(.136)\end{array}$ & $>.99$ \\
\hline & IL III-V & $\begin{array}{l}1.908 \\
(.213)\end{array}$ & $\begin{array}{l}1.925 \\
(.128)\end{array}$ & $>.99$ & $\begin{array}{l}1.745 \\
(.285)\end{array}$ & $>.99$ & $\begin{array}{l}1.842 \\
(.028)\end{array}$ & $\begin{array}{l}1.842 \\
(.116)\end{array}$ & $>.99$ & $\begin{array}{l}1.953 \\
(.109)\end{array}$ & .32 \\
\hline & IL I-V & $\begin{array}{l}3.411 \\
(.312)\end{array}$ & $\begin{array}{l}3.449 \\
(.143)\end{array}$ & $>.99$ & $\begin{array}{l}3.24 \\
(.291)\end{array}$ & $>.99$ & $\begin{array}{l}3.362 \\
(.153)\end{array}$ & $\begin{array}{l}3.433 \\
(.245)\end{array}$ & $>.99$ & $\begin{array}{l}3.514 \\
(.130)\end{array}$ & .22 \\
\hline & AR V/I & $\begin{array}{l}1.542 \\
(1.739)\end{array}$ & $\begin{array}{l}1.238 \\
(.832)\end{array}$ & $>.99$ & $\begin{array}{l}1.174 \\
(.517)\end{array}$ & $>.99$ & $\begin{array}{l}1.349 \\
(.946)\end{array}$ & $\begin{array}{l}1.1310 \\
(.398)\end{array}$ & $>.99$ & $\begin{array}{l}1.326 \\
(.287)\end{array}$ & $>.99$ \\
\hline \multirow[t]{4}{*}{$16 k$} & IL I-III & $\begin{array}{l}1.560 \\
(.160)\end{array}$ & $\begin{array}{l}1.540 \\
(.131)\end{array}$ & $>.99$ & $\begin{array}{l}1.490 \\
(.145)\end{array}$ & 0.25 & $\begin{array}{l}1.560 \\
(.147)\end{array}$ & $\begin{array}{l}1.540 \\
(.084)\end{array}$ & $>.99$ & $\begin{array}{l}1.561 \\
(.062)\end{array}$ & $>.99$ \\
\hline & IL III-V & $\begin{array}{l}1.822 \\
(.257)\end{array}$ & $\begin{array}{r}1.943 \\
(.091)\end{array}$ & $>.99$ & $\begin{array}{l}1.862 \\
(.113)\end{array}$ & $>.99$ & $\begin{array}{l}1.863 \\
(.113)\end{array}$ & $\begin{array}{l}1.933 \\
(.166)\end{array}$ & .85 & $\begin{array}{l}1.9630 \\
(.050)\end{array}$ & $>.99$ \\
\hline & IL I-V & $\begin{array}{l}3.383 \\
(.395)\end{array}$ & $\begin{array}{l}3.483 \\
(.218)\end{array}$ & $>.99$ & $\begin{array}{l}3.353 \\
(.248)\end{array}$ & $>.99$ & $\begin{array}{l}3.423 \\
(.252)\end{array}$ & $\begin{array}{l}3.474 \\
(.214)\end{array}$ & $>.99$ & $\begin{array}{l}3.5236 \\
(.094)\end{array}$ & $>.99$ \\
\hline & AR V/I & $\begin{array}{l}.979 \\
(.410)\end{array}$ & $\begin{array}{l}.9067 \\
(.320)\end{array}$ & .69 & $\begin{array}{l}1.310 \\
(.410)\end{array}$ & $>.99$ & $\begin{array}{l}1.178 \\
(.913)\end{array}$ & $\begin{array}{l}1.278 \\
(1.470)\end{array}$ & $>.99$ & $\begin{array}{l}1.078 \\
(.289)\end{array}$ & $>.99$ \\
\hline
\end{tabular}




\begin{tabular}{|c|c|c|c|c|c|c|c|c|c|c|c|}
\hline \multirow[t]{4}{*}{$24 k$} & IL I-III & $\begin{array}{l}1.550 \\
(.157)\end{array}$ & $\begin{array}{l}1.550 \\
(.130)\end{array}$ & $>.99$ & $\begin{array}{l}1.570 \\
(.232)\end{array}$ & $>.99$ & $\begin{array}{l}1.560 \\
(.113)\end{array}$ & $\begin{array}{l}1.520 \\
(.090)\end{array}$ & $>.99$ & $\begin{array}{l}1.621 \\
(.120)\end{array}$ & $>.99$ \\
\hline & IL III-V & $\begin{array}{l}1.853 \\
(.186)\end{array}$ & $\begin{array}{l}2.004 \\
(.135)\end{array}$ & 0.25 & $\begin{array}{l}1.974 \\
(.180)\end{array}$ & $>.99$ & $\begin{array}{l}1.712 \\
(.202)\end{array}$ & $\begin{array}{l}1.893 \\
(.293)\end{array}$ & .25 & $\begin{array}{l}1.750 \\
(.200)\end{array}$ & $>.99$ \\
\hline & IL I-V & $\begin{array}{l}3.403 \\
(.329)\end{array}$ & $\begin{array}{l}3.554 \\
(.243)\end{array}$ & 0.26 & $\begin{array}{l}3.544 \\
(.309)\end{array}$ & $>.99$ & $\begin{array}{l}3.272 \\
(.250)\end{array}$ & $\begin{array}{l}3.413 \\
(.279)\end{array}$ & $>.99$ & $\begin{array}{l}3.371 \\
(.147)\end{array}$ & .51 \\
\hline & AR V/I & $\begin{array}{l}.957 \\
(.242)\end{array}$ & $\begin{array}{l}.916 \\
(.594)\end{array}$ & $>.99$ & $\begin{array}{l}1.11 \\
(.595)\end{array}$ & $>.99$ & $\begin{array}{l}.536 \\
(.265)\end{array}$ & $\begin{array}{l}.445 \\
(.305)\end{array}$ & .50 & $\begin{array}{l}.834 \\
(.470)\end{array}$ & .50 \\
\hline \multirow[t]{4}{*}{$32 \mathrm{k}$} & IL I-III & $\begin{array}{l}1.550 \\
(.109)\end{array}$ & $\begin{array}{l}1.478 \\
(.093)\end{array}$ & $>.99$ & $\begin{array}{l}1.428 \\
(.261)\end{array}$ & $>.99$ & $\begin{array}{l}1.570 \\
(.097)\end{array}$ & $\begin{array}{l}1.520 \\
(.066)\end{array}$ & .23 & $\begin{array}{l}1.570 \\
(.157)\end{array}$ & $>.99$ \\
\hline & IL III-V & $\begin{array}{l}1.883 \\
(.318)\end{array}$ & $\begin{array}{l}2.010 \\
(.376)\end{array}$ & $>.99$ & $\begin{array}{l}1.850 \\
(.240)\end{array}$ & $>.99$ & $\begin{array}{l}1.822 \\
(.065)\end{array}$ & $\begin{array}{l}1.903 \\
(.272)\end{array}$ & $>.99$ & $\begin{array}{l}1.862 \\
(.366)\end{array}$ & $>.99$ \\
\hline & IL I-V & $\begin{array}{l}3.433 \\
(.400)\end{array}$ & $\begin{array}{l}3.488 \\
(.372)\end{array}$ & $>.99$ & $\begin{array}{l}3.278 \\
(.416)\end{array}$ & $>.99$ & $\begin{array}{l}3.393 \\
(.145)\end{array}$ & $\begin{array}{l}3.423 \\
(.283)\end{array}$ & $>.99$ & $\begin{array}{l}3.433 \\
(.362)\end{array}$ & $>.99$ \\
\hline & $\mathrm{AR} \mathrm{V/I}$ & $\begin{array}{l}.491 \\
(.437)\end{array}$ & $\begin{array}{l}.505 \\
(.278)\end{array}$ & .69 & $\begin{array}{l}.617 \\
(.523)\end{array}$ & .28 & $\begin{array}{l}.404 \\
(.296)\end{array}$ & $\begin{array}{l}.551 \\
(.209)\end{array}$ & .50 & $\begin{array}{l}.870 \\
(.961)\end{array}$ & .45 \\
\hline
\end{tabular}

2 Abbreviations: $\mathrm{CIC}=$ central nucleus of interior colliculus, $\mathrm{DCBN}=$ dentate cerebellar nucleus, stim-off $=$ stimulation-off state, LFS $=$

3 deep brain stimulation at $10 \mathrm{~Hz}, \mathrm{HFS}=$ deep brain stimulation at $100 \mathrm{~Hz}$. 


\section{Figure 1}

Surgery of implantation of ABR and DBS electrodes.

A. After exposing the skull, the vertex electrode is attached with a screw in the skull and the mastoid electrode is subcutaneously tunneled to the mastoid and also fixated with a screw. Three boreholes are made for anchoring screws to later fixate the structure with dental cement. B. Boreholes for the DBS electrodes are drilled at coordinates calculated from the bregma level. Calculation of the boreholes and placement of the DBS electrodes are performed within a stereotactic frame. C. All electrodes are in place and the construct is fixated with dental cement.

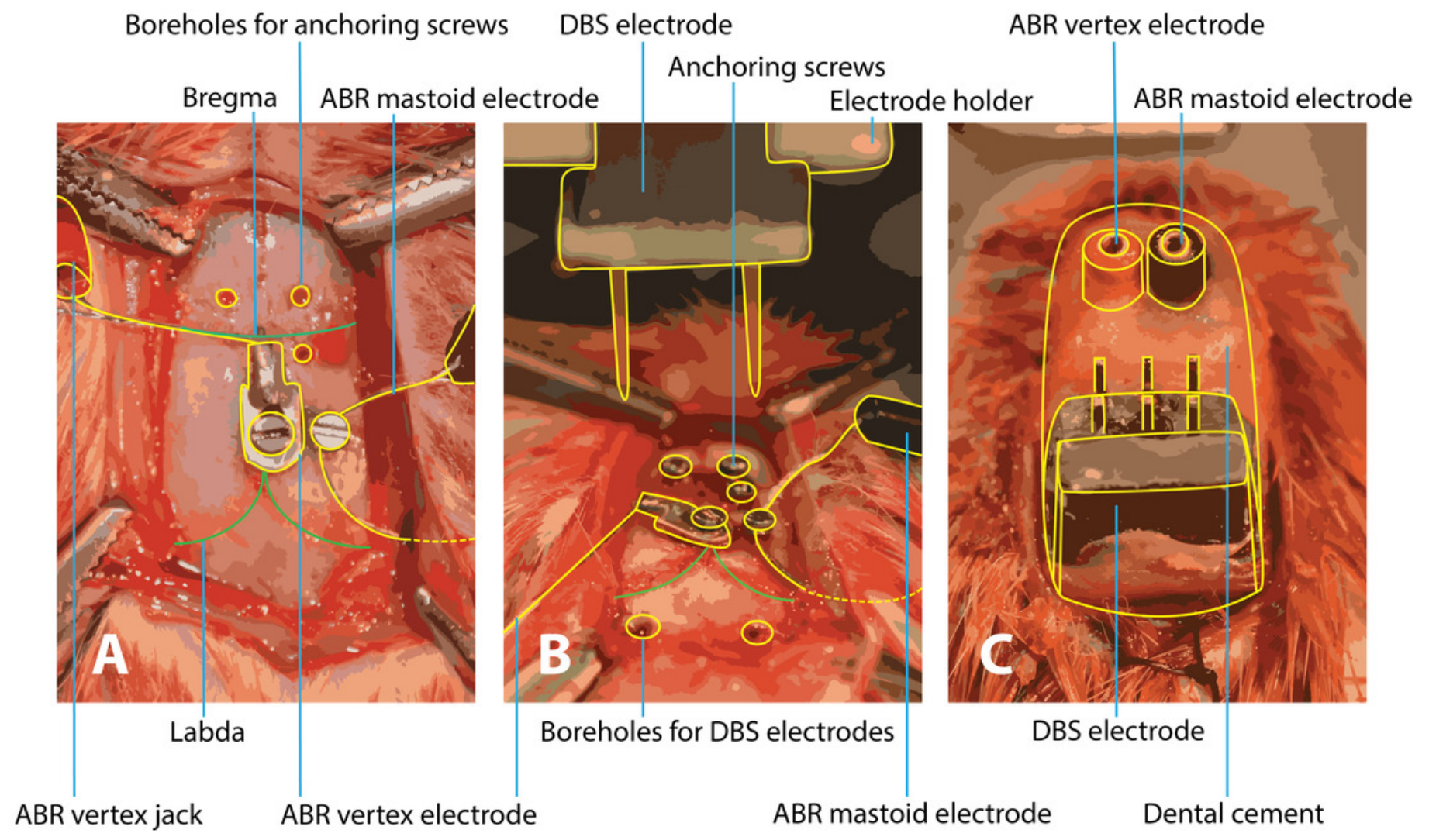




\section{Figure 2 (on next page)}

ABR signal processing

A. Example of a raw signal that was measured during low frequency stimulation (LFS). B. Stimulation artifacts are filtered with automatic peak detection analysis. C. Example of an auditory brainstem response (ABR) (burst frequency $10 \mathrm{kHz}$ ) during off-stimulation state, during LFS and during high frequency stimulation (HFS) in the central nucleus of the inferior colliculus (CIC). The five ABR peaks are numbered I-V. Morphology and latency of ABR peaks in the current study were consistent with other animal studies (Backoff and Caspary, 1994; Dehmel et al., 2012; Zheng et al., 2012). The first peak arises approximately 1.5 ms after stimulus onset. Although there is overlap, the first peak represents neural activity of the cochlear nerve. The second peak is considered to be mainly generated by cochlear nuclear cells, the third peak by the contralateral superior olivary complex cells and the fourth peak by the lateral lemniscus. The fifth peak, which appears approximately $5 \mathrm{~ms}$ after onset, originates from the IC (Biacabe et al., 2001; Chen and Chen, 1991; Simpson et al., 1985). 


\section{Figure 3}

Histology

Representative examples of electrode positions (white lines) in the CIC (A) and DCBN (B). All electrodes were implanted bilaterally. $\mathrm{ECIC}=$ external nucleus of the inferior colliculus, $\mathrm{CIC}=$ central nucleus of inferior colliculus, $\mathrm{DCIC}=$ dorsal cortex of inferior colliculus, $\mathrm{DCBN}=$ dentate cerebellar nucleus, icp = inferior cerebellar peduncle, ICBN = interposed cerebellar nucleus, $\mathrm{scp}=$ superior cerebellar peduncle. Scale bar: $500 \mu \mathrm{m}$.

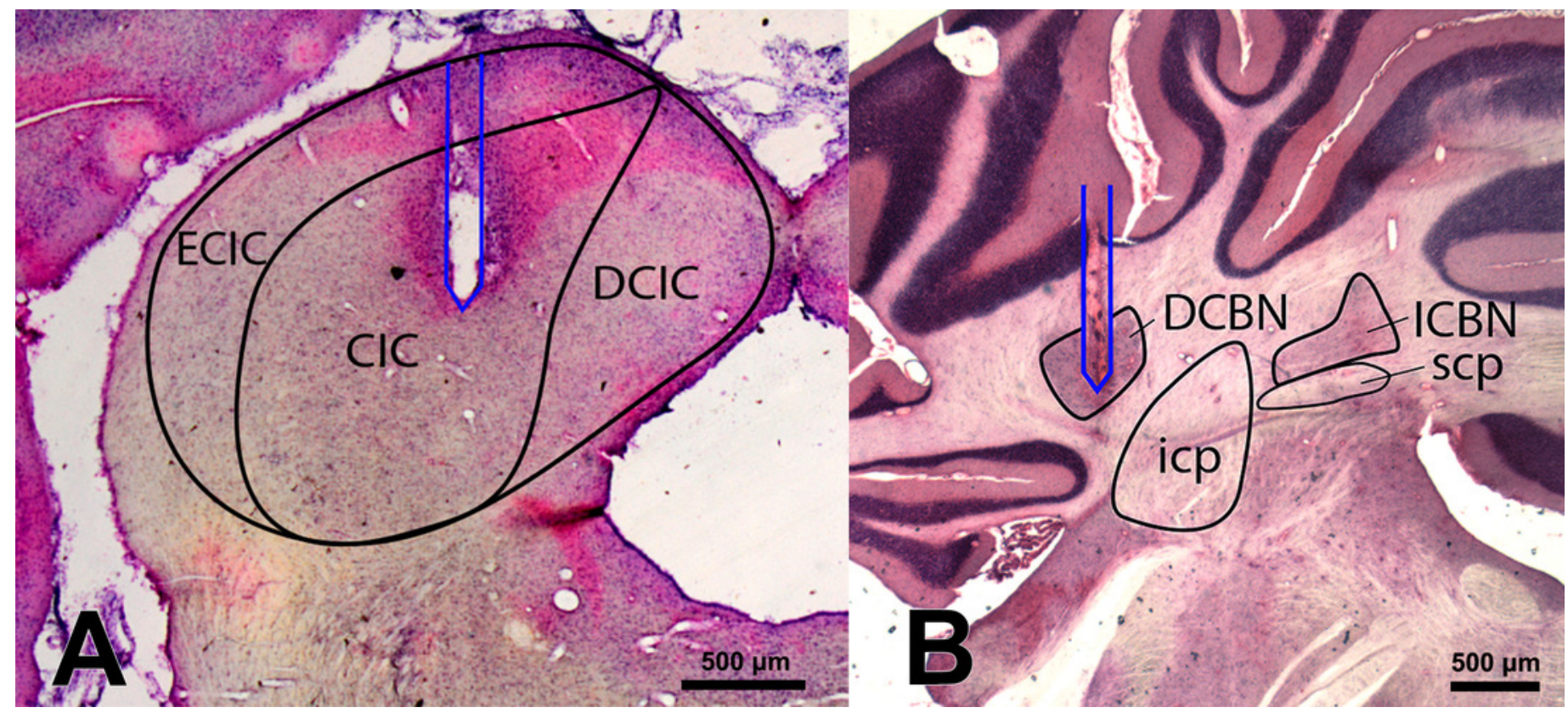


Figure 4(on next page)

ABR thresholds

ABR thresholds of the CIC (A) and DCBN group (B) measured during the DBS-off state (blue, circles, solid line), LFS (green, squares, striped line) and HFS (red, triangles, dotted line). There was no statistically significant difference. The vertical lines indicate the standard error of the mean. 
CNIC

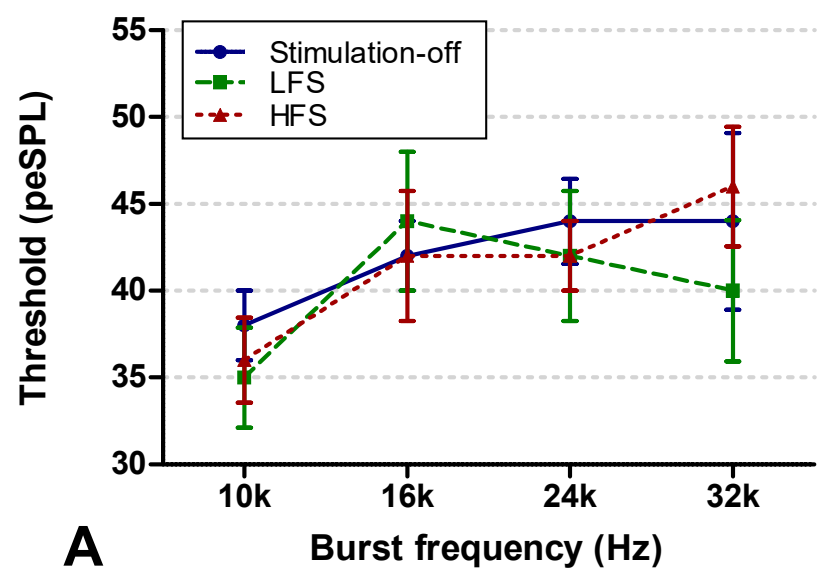

DCBN

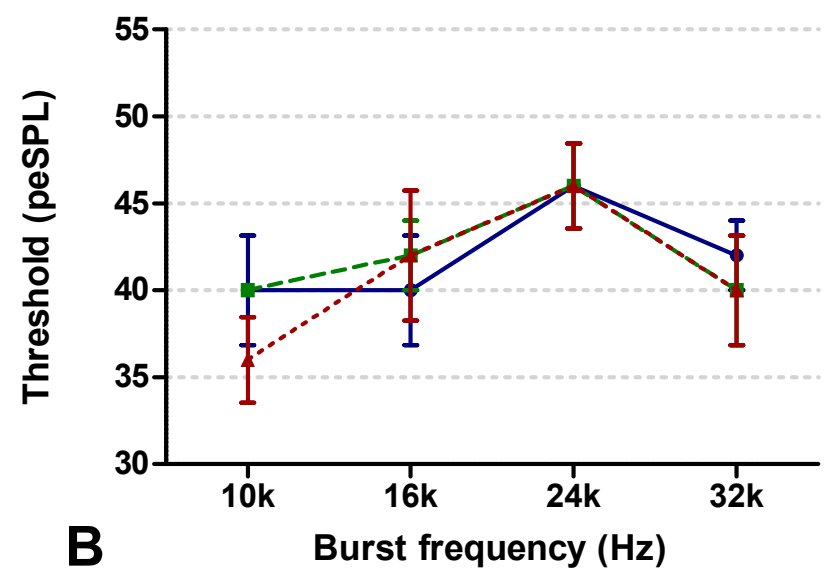

